\title{
Biogeochemistry
}

June 2014, Volume 119, Issue 1-3, Pages 35-43

http://dx.doi.org/10.1007/s10533-013-9924-3

Archimer

(C) Springer Science+Business Media Dordrecht 2013

The original publication is available at http://www.springerlink.com

\section{A Michaelis-Menten type equation for describing methylmercury dependence on inorganic mercury in aquatic sediments}

\author{
Daniel Cossa ${ }^{1,2,{ }^{*}}$, Cédric Garnier ${ }^{3}$, Roselyne Buscail ${ }^{4}$, Francoise Elbaz-Poulichet ${ }^{5}$, \\ Nevenka Mikac ${ }^{6}$, Nathalie Patel-Sorrentino ${ }^{3}$, Erwan Tessier ${ }^{3}$, Sylvain Rigaud ${ }^{7}$, Véronique Lenoble ${ }^{3}$, \\ Charles Gobeil $^{8}$ \\ ${ }^{1}$ IFREMER, BP 330, 83507, La Seyne-sur-Mer, France \\ 2 ISTerre, Université J. Fourier, BP 53, 38041, Grenoble, France \\ ${ }^{3}$ PROTEE, Université de Toulon, EA 3819, 83957, La Garde, France \\ ${ }^{4}$ CEFREM-CNRS-UMR 5110, Université de Perpignan, 52 Avenue P. Alduy, 66860, Perpignan, France \\ ${ }^{5}$ Laboratoire Hydrosciences, UMR CNRS, Universités Montpellier I \& II, Place E. Bataillon, CC MSE, 34095, \\ Montpellier Cedex 5, France \\ ${ }_{7}^{6}$ Center for Marine and Environmental Research, Ruđer Bošković Institute, PO Box 1016, 10000, Zagreb, Croatia \\ ${ }^{7}$ Cerege, Aix-Marseille Université, Europole Méditerranéen de l'Arbois, BP 80, 13545, Aix-en-Provence Cedex \\ 04, France \\ ${ }^{8}$ INRS-ETE, Université du Québec, 490 de la Couronne, Quebec, QC, G1K 9A9, Canada
}

*: Corresponding author : Daniel Cossa, email address : dcossa@ifremer.fr cgarnier@univ-tIn.fr ; buscail@univ-perp.fr ; felbaz@univ-montp2.fr ; mikac@irb.hr ; rigaud@cerege.fr ; gobeilch@ete.inrs.ca

\begin{abstract}
:
Methylation of mercury $(\mathrm{Hg})$ is the crucial process that controls $\mathrm{Hg}$ biomagnification along the aquatic food chains. Aquatic sediments are of particular interest because they constitute an essential reservoir where inorganic divalent $\mathrm{Hg}\left(\mathrm{Hg}^{\prime \prime}\right)$ is methylated. Methylmercury $(\mathrm{MeHg})$ concentrations in sediments mainly result from the balance between methylation and demethylation reactions, two opposite natural processes primarily mediated by aquatic microorganisms. Thus, $\mathrm{Hg}$ availability and the activity of methylating microbial communities control the $\mathrm{MeHg}$ abundance in sediments. Consistently, some studies have reported a significant positive correlation between $\mathrm{MeHg}$ and $\mathrm{Hg}$ " or total $\mathrm{Hg}\left(\mathrm{Hg}_{\mathrm{T}}\right)$, taken as a proxy for $\mathrm{Hg}^{\prime \prime}$, in aquatic sediments using enzyme-catalyzed methylation/demethylation mechanisms. By compiling 1,442 published and unpublished $\mathrm{Hg}_{\mathrm{T}}-\mathrm{MeHg}$ couples from lacustrine, riverine, estuarine and marine sediments covering various environmental conditions, from deep pristine abyssal to heavily contaminated riverine sediments, we show that a Michaelis-Menten type relationship is an appropriate model to relate the two parameters: $\mathrm{MeHg}=a \mathrm{Hg}_{\mathrm{T}} /\left(\mathrm{K}_{m}+\mathrm{Hg}_{\mathrm{T}}\right)$, with $a=0.277 \pm 0.011$ and $K_{m}=188 \pm 15\left(R^{2}=0.70, p<0.001\right)$. From $K_{m}$ variations, which depend on the various encountered environmental conditions, it appears that $\mathrm{MeHg}$ formation and accumulation are favoured in marine sediments compared to freshwater ones, and under oxic/suboxic conditions compared to anoxic ones, with redox potential and organic matter lability being the governing factors.
\end{abstract}

Keywords: Mercury ; Methylmercury ; Aquatic sediment ; Methylation ; Demethylation 


\section{Introduction}

Methylmercury $(\mathrm{MeHg})$, mercury $(\mathrm{Hg})$ most toxic form, bioconcentrates in organisms and biomagnifies along the aquatic food chains (Clarkson and Magos 2006). Although $\mathrm{MeHg}$ concentrations in sediments can be affected by exchanges with the water column, the main controlling factor of these concentrations appears to be the balance between $\mathrm{Hg}^{\prime \prime}$ in situ methylation and $\mathrm{MeHg}$ demethylation reactions, two opposite natural processes primarily mediated by aquatic microorganisms (e.g., Ullrich et al. 2001; Barkay et al. 2011; Gilmour et al. 2011; Yu et al. 2012). Despite some early laboratory experiments which suggested that $\mathrm{Hg}^{\prime \prime}$ methylation results from the activity of many aerobic and anaerobic microorganisms (Jensen and Jernelöv 1969; Vonk and Sijpesteijn 1973), more recent researches showed that methylation capacity in aquatic sediments is limited to anaerobic bacteria, including sulfate-reducing bacteria (SRB) (Compeau and Bartha 1984 and 1985; Choi et al. 1994; Baldi 1997), iron-reducing bacteria (IRB) (Fleming et al. 2006; Kerin et al. 2006; Yu et al. 2012) and methanogens (Hamelin et al. 2011). Furthermore, environmental incubations also suggested that SRB and IRB are the main mercury methylators in natural environments (Gilmour et al. 1992, 2011; Yu et al. 2010, 2012; Acha et al. 2012), with SRB being the dominant community (Choi et al. 1994; Baldi 1997; Pak and Bartha 1998; Yu et al. 2010). On the other hand, $\mathrm{MeHg}$ demethylation results from numerous types of microorganisms in both aerobic and anoxic environments (Oremland et al. 1991; Dahlberg and Hermansson 1995; Pearson et al. 1996; Marvin-Dipasquale and Oremland 1998; Marvin-Dipasquale et al. 2000), either by reductive or oxidative demethylation (Barkay et al. 2011; Mason 2012). In oxidative demethylation, active in SRB and methanogens, $\mathrm{MeHg}$ is converted into $\mathrm{Hg}^{\prime \prime}$, whereas in reductive demethylation, more extensively distributed throughout microbial communities, $\mathrm{MeHg}$ is converted into $\mathrm{Hg}^{0}$.

For bacterial Hg" methylation, Parks et al. (2013) recently reported a two-gene cluster (HgcA and $\mathrm{HgcB}$ ), suggesting a common $\mathrm{Hg}$ pathway in all methylating bacteria hitherto sequenced, including SRB, IRB and methanogen strains. Radiolabelled experiments suggested that a methyl group of methyltetrahydrofolate, from the acetyl-CoA pathway, is transferred to $\mathrm{HgcA}$ as $\mathrm{CH}_{3}{ }^{+}$, consistently with the enzyme-catalyzed methylation pathway earlier proposed by Choi et al. (1994). For $\mathrm{MeHg}$ demethylation, multiple enzymatic pathways coexist. The oxidative demethylation, primarily producing $\mathrm{CO}_{2}$, seems ubiquitous in anaerobic sediments (Oremland et al. 1991), whereas reductive pathway, producing mainly $\mathrm{CH}_{4}$ (via the organomercurial-lyase pathway, Begley et al. 1986), dominates in aerobic sediments or under anaerobic incubations of highly contaminated sediments (MarvinDipasquale et al. 2000; Schaefer et al. 2002; Segade et al. 2010).

All these proposed pathways suggested that an enzymatic model between $\mathrm{MeHg}$ net formation and its substrate concentration $\left(\mathrm{Hg}^{\text {II })}\right.$ should be shared in every sedimentary situation. Indeed, Gilmour et al. (2011) found a strong positive relationship between $\mathrm{MeHg}$ production and the log of the total $\mathrm{Hg}$ concentration obtained in a controlled experiment involving a SRB, Desulfovibrio desulfuricans. King et al. (1999) also found a nonlinear relationship between rates of $\mathrm{MeHg}$ formation as a function of $\mathrm{Hg}$ " added in sediment slurries, consistent with a first-order Michaelis-Menten model. Besides the results of these experimental approaches, several field studies converged to find significant positive relationships between $\mathrm{Hg}^{\prime \prime}$ or $\mathrm{HgT}$, and $\mathrm{MeHg}$ in freshwater, brackish and marine sediments (e.g., Benoit et al. 2003; Hammerschmidt and Fitzgerald 2006; Drott et al. 2008; MarvinDipasquale et al. 2009; Gilmour et al. 2011). These empirical relationships also suggested that net $\mathrm{MeHg}$ production in aquatic sediments is limited by $\mathrm{Hg}^{\prime \prime}$ availability, if $\mathrm{HgT}$ is assumed as a proxy for $\mathrm{Hg}^{\prime \prime}$ substrate for methylation, which is reasonable since $\mathrm{MeHg}$, in most cases, represents less than $1 \%$ of sedimentary $\mathrm{HgT}$. Testing various substratum 
including cinnabar, metacinnabar, $\mathrm{Hg}^{\prime \prime}$ bound to mackinavite or organic matter (OM), Jonsson et al. (2012) reported $\mathrm{Hg}$ methylation rates spanning over 2 orders of magnitude, increasing with $\mathrm{Hg}^{\prime \prime}$ dissolution or desorption from solids. Besides mobilization from solid, OM was also suggested as a key-parameter of $\mathrm{Hg}$ sediment-water partitioning and bioavailability, which seems to constrain $\mathrm{MeHg} / \mathrm{HgT}$ in surface sediments (e.g., Sunderland et al., 2006; Hammerschmidt and Fitzgerald, 2006; Schartup et al., 2013). Lastly, large differences between estimations of $\mathrm{Hg}$ methylation rates exist, depending on environmental conditions, which are not directly related to $\mathrm{Hg}^{\text {"I }}$ bioavailability, but rather to changes in the present microbial communities (Ranchou-Peyruse et al. 2009; Segade et al. 2010; Mason 2012; Husu-Kim et al. 2013).

In order to further examine the environmental conditions that control net $\mathrm{Hg}$ methylation and limit $\mathrm{MeHg}$ accumulation in aquatic sediments, we propose the use of a model resembling Michaelis-Menten kinetics synthesizing the enzymatic methylation and demethylation reactions. We thus applied this type of model to $1442 \mathrm{MeHg} / \mathrm{HgT}$ couples, collected in scientific literature or from our unpublished works. The gathered data cover sedimentary environments from surface to deep layers including abyssal, coastal, lagoonal, estuarine, lacustrine and riverine sediments, and range from pristine to heavily polluted areas and from aerobic to sulfidic environments. It appears that a Michaelis-Menten equation significantly $(p<$ 0.001) relates $\mathrm{MeHg}$ to $\mathrm{HgT}$ concentrations accordingly to the converging hypotheses of Benoit et al. (2003), Drott et al. (2007, 2008), Hammerschmidt et al. (2008), Sparling (2009), Frohne et al. (2012) and others. Apparent half-saturation value $\left(K_{m}\right)$ of the model depends on the various encountered environmental conditions, with redox potential and organic matter lability as the governing factors.

\section{Material and methods}

Unpublished data ( $\mathrm{N}=602)$ originated from sediment cores collected from Mediterranean environments, including near-shore environments (Pierre-Blanche lagoon and Toulon bay), continental shelf (Rhone pro-delta), canyon (Cap de Creus), abyssal plain (Algero-Provencal and Ionian basins), and Arctic Ocean margin and deep basins. $\mathrm{HgT}$ and $\mathrm{MeHg}$ determinations were performed according to Abi-Ghanen et al. (2011).

The gathered data $(\mathrm{N}=840)$ used here originated from published works mentioned in Table 1. When figure data were not available, the DigiSoft program (available for free, download at: http://gss.srce.hr/pithos/rest/omanovic@irb.hr/files/Software/) software was used to convert data points of the published graphs into numerals.

The Michaelis-Menten equation is frequently used to describe enzyme-catalyzed processes, as it relates to the metabolic conversion of a compound. The Michaelis-Menten fitting has successively described the methylation rate $\mathrm{vs} \mathrm{Hg}^{\prime \prime}$ concentration from experiments performed either on isolated bacteria strain (e.g. the Desulfovibrio desulfuricans LS isolated from salt marsh sediment, Choi et al. 1994), or directly on bulk sediments (e.g. King et al. 1999). Although normally used to model kinetic results (i.e. product formation rate vs substrate concentration), some authors also used such relationships between product and substrate concentrations. For instance, $\mathrm{MeHg}$ or $\mathrm{HgT}$ contents in fish tissues vs aqueous $\mathrm{Hg}_{\mathrm{T}}$ were properly depicted using Michaelis-Menten curves by Brent and Kain (2011) and Mathews et al. (2013), respectively. Even empirical, such fits offer the advantage of a mechanistic foundation (i.e. enzymatic processes governing $\mathrm{Hg}$ methylation) and provide benchmarks for maximum methylation and half-saturation constant, parameters which can 
be confronted to laboratory or field experiments. Michaelis-Menten model was fit using SigmaPlot 10.0 software.

\section{Results and discussion}

The data couples spanned over six and five orders of magnitude for $\mathrm{HgT}$ and $\mathrm{MeHg}$, respectively: from $3.1 \times 10^{-3}$ to $1.1 \times 10^{3} \mathrm{nmol} \mathrm{g}^{-1}$ and from $3.9 \times 10^{-5}$ to $3.6 \times 10^{-1} \mathrm{nmol} \mathrm{g}^{-1}$, thus going from pristine to heavily contaminated sediments. Considering the entire data set, we achieved a highly significant $\left(R^{2}=0.70, N=1442, p<0.001\right)$ overall relationship with the following equation:

$$
\mathrm{MeHg}=\frac{a \times H g_{T}}{K_{m}+H g_{T}},
$$

where " $a$ " is the saturation MeHg concentration $\left(0.277 \pm 0.011 \mathrm{nmol} \mathrm{g}^{-1}\right)$ and " $K_{m}$ " estimates the $\mathrm{HgT}$ concentration, which corresponds to MeHg half-saturation (188 $\left.\pm 15 \mathrm{nmol} \mathrm{g}^{-1}\right)$ (Fig. 1). As $\mathrm{Km}$ increases, methylation efficiency decreases.

This Michaelis-Menten function corroborates that sediment MeHg concentrations are directly dependent of $\mathrm{HgT}$ concentration taken as a proxy of the methylation substrate $\left(\mathrm{Hg}^{\text {II }}\right)$, with an asymptotic MeHg concentration (a) mainly defined by data from Sweden riverine and estuarine sediments heavily contaminated by chlor-alkali activities (Drott et al. 2008). Such a saturation point was already noticed for contaminated sediments by Benoit et al. (2003). This maximum, theoretically due to $\mathrm{Hg}^{\prime \prime}$ saturation of the methylation enzymatic systems, illustrates a more complex situation earlier qualified as "mercury accumulation paradox" (Schaefer et al. 2004). The Michaelis-Menten type relationship calculated here is the combination of multiple counteracting enzymatic reactions. As suggested by several authors (Marvin-Dipasquale and Oremland 1998; Marvin-Dipasquale et al. 2000; Segade et al. 2010), the asymptotic $\mathrm{MeHg}$ concentration can be interpreted as a modification of the reductive demethylation pathways in contaminated sediments, resulting from a methanogen to SRB demethylation shift when $\mathrm{Hg}^{\prime \prime}$ or $\mathrm{MeHg}$ contents exceed a threshold value. Oxidative or reductive demethylation pathways would have indeed striking different consequences in the mercury cycling in the sediment. As quoted by Segade et al. (2010), the end-product of the reductive demethylation is gaseous $\mathrm{Hg}^{0}$, a species which can escape from the sediment allowing its real detoxification, whereas the oxidative demethylation generates an $\mathrm{Hg}^{\text {" }}$ endproduct which may be recycled in the methylation pathway.

The $K_{m}$ value $\left(188 \pm 15 \mathrm{nmol} \mathrm{g}{ }^{-1}\right)$ constitutes a relatively stable estimate, as the coefficient of variation falls below $8 \%$. However, keeping the asymptotic a value of the equation fixed at $0.277 \mathrm{nmol} \mathrm{g}^{-1}$, peculiar $K_{m}$ values exhibit large variations (Table 2) depending on the environmental characteristics and sites, illustrated by the $K_{m}$ increase when methylation efficiency decreases. Ranking the $1442 \mathrm{HgT}-\mathrm{MeHg}$ couples according to their $K_{m}$ values, it appears that (i) $5 \%$ of $\mathrm{HgT}-\mathrm{MeHg}$ couples are lower than 26.5 , with $93 \%$ and $75 \%$ of them are from surface sediments $(\leq 2 \mathrm{~cm})$ and pristine sediment, respectively, and that (ii) $5 \%$ highest $K_{m}$ values are higher than 825 , with $97 \%$ of them correspond to deep $(>10 \mathrm{~cm}$ ) contaminated sediments. In addition, relatively low $K m$ values $\left(139 \pm 12 \mathrm{nmol} \mathrm{g} \mathrm{g}^{-1}\right)$ characterizes surface sediments $(\leq 2 \mathrm{~cm})$ compared to that of sediments collected below 10 $\mathrm{cm}$ depth (223 $\pm 10 \mathrm{nmol} \mathrm{g}^{-1}$, Table 2). Furthermore, the $\mathrm{Km}$ values for the samples collected in open ocean are much lower than those for the river samples, whereas intermediate values characterized coastal and lagoonal samples (Table 2). 
Interestingly, the Michaelis-Menten model can be simplified, for $\mathrm{HgT} \ll K m$, as a simple ratio: $\mathrm{MeHg}=b \times \mathrm{Hg}_{T}$ with $b=\frac{a}{K_{m}} \times 100$. The calculated $b$ value is $0.15 \%$ for our entire data set, and ranges from 0.03 to $1.05 \%$ for the lowest and highest methylation efficiencies, respectively (see Supplementary information Fig. SI1). This is consistent with previous observations showing that $\mathrm{MeHg} / \mathrm{HgT}$ ratios are a good proxy for net $\mathrm{Hg}$ methylation rates (e.g. Benoit et al. 2003; Hammerschmidt and Fitzgerald 2004, 2006; Guimarães et al. 2006; Drott et al. 2008). However, for the highest $\mathrm{HgT}$ values, the $\mathrm{MeHg} / \mathrm{HgT}$ ratios notably decrease (Fig. SI2). This suggests that a "ratio model" does not fit the entire data set and, consequently, the diversity of the encountered environmental situations, as the MichaelisMenten model does.

In summary, (i) sediments collected at depth $>10 \mathrm{~cm}(\mathrm{~N}=228)$ exhibit higher $K_{m}$ than surface ones $(0-2 \mathrm{~cm})$, and (ii) freshwater and contaminated coastal sediments exhibit higher $K_{m}$ than marine sediments. In other words, oxic/suboxic sediments and those originating from autochthonous marine settling material present higher net methylation rates than anoxic and/or continental derived sediments. It also suggests that authigenic particles from the water column may be MeHg-enriched before being deposited and incorporated in surficial sediment, as earlier suggested by Muresan et al. (2007) for a lagoonal environment. Gilmour et al. (1998) and Benoit et al. (2003) already noticed that highest $\mathrm{MeHg} / \mathrm{Hg}$ ratios were found in sediments where sulfate reduction was high but sulfide accumulation was low, such as sediments' upper layers and continental slopes. Han et al. (2010) also concluded from experiments with sulfate-limited sediments that $\mathrm{Hg}^{\text {" }}$ active methylation "possibly occurred by syntrophic processes arising between methanogens and sulfidogens". It has been recognized that in mildly reductive conditions, $\mathrm{HgS}^{0}{ }_{(\mathrm{aq})}, \mathrm{Hg}(\mathrm{SH})^{0}{ }_{(\mathrm{aq})}$ and uncharged mercury molecules such as $\mathrm{Hg}$-cysteine complexes or even $\mathrm{HgS}$ particles facilitate mercury uptake in methylator microorganisms (Benoit et al. 1999; Drott et al. 2007; Schaefer and Morel 2009; Graham et al. 2012). Conversely, enhancement of dissolved sulfide in anoxic sediments may inhibit MeHg production (Benoit et al. 1999; Hammerschmidt et al. 2008). It is interesting to note that high $\mathrm{Km}$ values for contaminated sediments are in agreement with the results of Drott et al. (2008) and Hines et al. (2000) showing that demethylation of MeHg progressively increases with depth in such sediments.

The differences between freshwater and marine sediments $K_{m}$ values are likely to be interpreted in terms of $\mathrm{OM}$ reactivity since the organic carbon (OC) taken as a whole does not seem to be an overall explanatory factor for $\mathrm{MeHg}$ concentration. Indeed, from the 617 $\mathrm{HgT}-\mathrm{MeHg}$ couples associated with OC contents, the significance of the $\mathrm{MeHg}$ vs OC relationship is not better than that of the $\mathrm{HgT}$ vs OC, and the $\mathrm{MeHg} / \mathrm{HgT}$ ratio appeared not to be related to OC (Fig. SI3 A, B and C). It is generally observed that OM is more abundant in river and near-shore sediments than in open ocean sediments. However, it is also generally accepted that the continental $\mathrm{OM}$ accumulated in rivers and estuaries is more mature than the freshly deposited $\mathrm{OM}$ in the high productive area of the ocean margins (Arnost and Holmer 2003). This suggests that labile fresh OM present at the shelf margin is more effective in fuelling the microbial methylating activity than refractory $\mathrm{OM}$, consistently with the hypothesis of Ravichandran (2004). To check the involvement of OM degradability in determining the relative $\mathrm{MeHg}$ abundance, we compared the $\mathrm{MeHg} / \mathrm{HgT}$ ratios with the amino acid concentrations available from the sediment of Cap de Creus canyon (Fig. 2). Considering nitrogenous compounds, especially amino acid, as the most hydrolysable OM present at the N.W. Mediterranean margin (Buscail and Germain 1997), it can be deduced from Figure 2 that the $\mathrm{OM}$ lability is a limiting factor of the $\mathrm{Hg}$ methylation. This evidence agrees with an earlier study on $\mathrm{MeHg}$ distribution in harbour marine sediments which stated that allochthonous organic material attenuates gross and net rates of $\mathrm{MeHg}$ production 
(Hammerschmidt et al. 2008). Drott et al. (2008) likewise showed that differences in the primary production and subsequent availability of easily degradable OM (serving as electron donor for methylating bacteria) was indicated to be the most important factor behind the observed differences in $\mathrm{MeHg} / \mathrm{HgT}$ ratios and so $K_{\mathrm{m}}$ values among sites.

We conclude that, in sulfidic and non sulfidic pristine and heavily polluted sediments from both freshwater and marine environments, the abundance of $\mathrm{MeHg}$ relative to $\mathrm{HgT}$ depens on $\mathrm{Hg}$ availability and $\mathrm{OM}$ reactivity. Oxic and suboxic sediments receiving both fresh $\mathrm{OM}$ and high $\mathrm{Hg}$ deposition, such as oceanic margins, favor $\mathrm{MeHg}$ accumulation. Only a part of $\mathrm{MeHg}$ is preserved in deep anoxic sediments leading to low $\mathrm{MeHg} / \mathrm{HgT}$ ratios. We can speculate furthermore that a Michaelis-Menten type model linking $\mathrm{MeHg}$ to inorganic $\mathrm{Hg}^{\mathrm{II}}$ could also be valid for the oceanic water column.

\section{Acknowledgements}

This research beneficiated from funding from the EXTREMA (ANR-06-VULN-005) and the HERMES-HERMIONE (GOCE-CT-2005-511234) projects funded by the Agence Nationale de la Recherche and the European Commission, respectively; from the CARTOCHIM project (funded by "Région PACA", "Toulon-Provence-Méditerranée (TPM)" and "l'Agence de l'Eau Rhône-Méditerranée et Corse"); was a part of the "MerMex-WP3-C3A" and international "IMBER" project. This publication reflects only the views of the authors, and the EC is not liable for any use that may be made of the information contained herein.

\section{References}

Abi-Ghanem C, Nakhlé K, Khalaf G, Cossa D (2011) Mercury distribution and methylmercury mobility in the sediments of three sites on the Lebanese Coast, Eastern Mediterranean. Arch Env Cont Tox 60:394-405

Acha D, Hintelmann H, Pabon CA (2012) Sulfate-reducing bacteria and mercury methylation in the water column of the lake 658 of the experimental lake area. GeoMicrob J 29:667674

Arnost C, Holmer M (2003) Carbon cycling in a continental margin sediment: Contrasts between organic matter characteristics and mineralization rates and pathways. Est Cstl Shelf Sci 58:197-208

Baldi F (1997) Microbial transformation of mercury species and their importance in the biogeochemical cycle of mercury. In: Sigel A, Sigel $\mathrm{H}$ eds. Metal lons in Biological Systems, vol. 34. Mercury and its Effects on Environment and Biology. Marcel Dekker Inc., NY, pp. 213-257.

Barkay T, Kroer N, Poulain AJ (2011) Some like it cold: microbial transformations of mercury in polar regions. Polar Research 30; DOI: 10.3402/polar.v30i0.15469

Benoit JM, Gilmour CC, Mason RP, Riedel GS, Riedel GF (1998) Behavior of mercury in the Patuxent river estuary Biogeochem 40:249-265

Benoit JM, Gilmour CC, Mason RP, Heyes A (1999). Sulfide controls on mercury speciation and bioavailability to methylating bacteria in sediment pore waters. Environ Sci Technol 33:951-957 
Benoit JM, Gilmour CC, Heyes A, Mason RP, Miller CL (2003) Geochemical and Biological Controls over Methylmercury Production and Degradation in Aquatic Ecosystems. In: Chai, Y., Braids, O.C. (Eds.), Biogeochemistry of Environmentally Important Trace Elements. ACS Symposium Series 835.

Begley TP, Walts AE, Walsh CT (1986) Mechanistic studies of a protonolytic organomercurial cleaving enzyme: bacterial organomercurial lyase. Biochemistry 25:7192-7200

Brent RN, Kain DG (2011) Development of an Empirical Nonlinear Model for Mercury Bioaccumulation in the South and South Fork Shenandoah Rivers of Virginia. Arch Environ Contam Toxicol61:614-623

Buscail R, Germain C (1997) Present-day organic matter sedimentation on the NW Mediterranean margin: Importance of off-shelf export. Limnol Oceanogr 42:217-229

Choi SC, Chase T, Bartha R (1994) Metabolic pathways leading to mercury methylation in Desulfovibrio desulfuricans LS. Appl Environl Microb 60:4072-4077

Clarkson TW, Magos L (2006) The toxicology of mercury and its chemical compounds. Crit Rev Toxicol 36:609-662

Compeau GC, Bartha R (1984) Methylation and demethylation of mercury under controlled redox, $\mathrm{pH}$ and salinity conditions. Appl Environ Microb 48:1203-1207

Compeau GC, Bartha R (1985) Sulfate-reducing bacteria: principal methylators of mercury in anoxic estuarine sediment. Appl Environ Microb 50:498-502

Dahlberg C, Hermansson M (1995) Abundance of Tn3, Tn21, and Tn501 transposase (tnpA) sequences in bacterial community DNAfrom marine environments. Appl Environ Microb 61:3051-3056

Drott A, Lambertsson L, Björn E, Skyllberg U (2007) Importance of dissolved neutral mercury sulfides for methyl mercury production in contaminated sediments. Environ Sci Technol 41:2270-2276

Drott A, Lambertsson L, Björn E, Skyllberg U (2008) Do potential methylation rates reflect accumulated methyl mercury in contaminated sediments? Environ Sci Technol 42:153158

Fleming, EJ, Mack EE, Green PG, Nelson DC (2006) Mercury methylation from unexpected sources: molybdate-inhibited freshwater sediments and an iron-reducing bacterium. Appl Environ Microb 72:457-464

Frohne T, Rinklebe J, Langer U, Du Laing G, Mothes S, Wennrich R (2012) Biogeochemical factors affecting mercury methylation rate in two contaminated floodplain soils. Biogeosciences 9:493-507

Gilmour CC, Henry EA, Mitchell R (1992) Sulfate stimulation of mercury methylation in freshwater sediments. Environ Sci Technol 26:2281-2287

Gilmour CC, Riedel GS, Ederington MC, Bell JT, Benoit JM, Gill GA, Stordal MC (1998) Methylmercury concentrations and production rates across a trophic gradient in the northern Everglades. Biogeochem 40:327-345

Gilmour CC, Elias DA, Kucken AM, Brown SD, Palumbo AV, Schadt CW, Wall JD (2011) Sulfate-reducing bacterium Desulfovibrio desulfuricans ND132 as a model for understanding bacterial mercury methylation. Appl Environ Microb 77:3938-3951

Graham AM, Aiken GR, Gilmour CC (2012) Dissolved organic matter enhances microbial mercury methylation under sulfidic conditions. Environ Sci Technol 46:2715-2723 
Guedron S, Huguet L, Vignati DAL, Liu B, Gimbert F, Ferrari BJD, Zonta R, Dominik J (2012) Tidal cycling of mercury and methylmercury between sediments and water column in the Venice Lagoon (Italy). Mar Chem 130:1-11

Guimarães JR, Mauro JB, Meili M, Sundbom M, Haglund AL, Coelho-Souza SA, Hylander LD (2006) Simultaneous radioassays of bacterial production and mercury methylation in the periphyton of a tropical and a temperate wetland. J Environ Manage 81:95-100

Hamelin S, Amyot M, Barkay T, Wang Y, Planas D (2011) Methanogens: principal methylators of mercury in lake periphyton. Environ Sci Technol 45:7693-7700

Hammerschmidt CR, Fitzgerald WF (2004) Geochemical controls on the production and distribution of methylmercury in near-shore marine sediments. Environ Sci Technol $38: 1487-1495$

Hammerschmidt CR, Fitzgerald WF (2006) Methylmercury cycling in sediments on the continental shelf of southern New England. Geochim Cosmochim Acta 70:918-930

Hammerschmidt CR, Fitzgerald WF, Balcom PH, Visscher PT (2008). Organic matter and sulfide inhibit methylmercury production in sediments of New York/New Jersey Harbor. Mar Chem 109:165-182

Han S, Obraztsova A, Pretto P, Choe KY, Gieskes J, Deheyn DD, Tebo BM (2007) Biogeochemistry factors affecting mercury methylation in sediments of the Venice lagoon, Italy. Env Tox Chem 26:655-663

Han S, Narasingarao P, Obraztsova A, Gieskes J, Hartmann AC, Tebo BM, Allen E, Deheyne DD (2010) Mercury Speciation in Marine Sediments under Sulfate-Limited Conditions. Environ Sci Technol 44:3752-3757

Hines ME, Horvat M, Faganeli J, Bonzongo JCJ, Barkay T, Majorf EB, Scott K, Bailey EA, Warwick JJ, Lyons WB (2000) Mercury Biogeochemistry in the Idrija River, Slovenia, from above the Mine into the Gulf of Trieste. Env. Res. 83:129-139

Hintelmann H, Wilken R-D (1995) Levels of total mercury and methylmercury compounds in sediments of the polluted Elbe River: influence of seasonally and spatially varying environmental factors. Sci Total Environ, 166:1-10

Hollweg TA, Gilmour CC, Mason RP (2010) Mercury and methylmercury cycling in sediments of the mid-Atlantic continental shelf and slope. Limnol Oceanogr 55:2703-2722

Hsu-Kim H, Kucharzyk KH, Zhang T, Deshusses MA (2013) Mechanisms Regulating Mercury Bioavailability for Methylating Microorganisms in the Aquatic Environment: A Critical Review. Environ. Sci. Technol., Just Accepted Manuscript. 05 Feb 2013

Jensen S, Jernelöv A (1969) Biological methylation of mercury in aquatic organisms. Nature 223:753-754

Jonsson S, Skyllberg U, Nilsson MB, Westlund PO, Shchukarev A (2012) Mercury Methylation Rates for Geochemically Relevant Hg" Species in Sediments. Environ Sci Technol 2012:11653-11659

Kerin EJ, Gilmour CC, Roden E, Suzuki MT, Coates JD, Mason RP (2006). Mercury methylation by dissimilatory iron-reducing bacteria. Appl and Environ Microb 72:7919 7921

King JK, Saunders FM, Lee RF, Jahnke RA (1999) Coupling mercury methylation rates to sulfate reduction rates in marine sediments. Environ Toxicol Chem 18:362-1369 
Kwokal Z, Franciskovic-Bilinski S, Bilinski H, Branica M (2002) A comparison of anthropogenic mercury pollution in Kaštela Bay (Croatia) with pristine estuaries in Ore (Sweden) and Krka (Croatia). Mar Poll Bull 44:1152-1169

Marvin-DiPasquale MC, Oremland RS (1998) Bacterial methylmercury degradation in Florida Everglad peat sediment. Environ Sci Technol 32:2556-2563

Marvin-DiPasquale MC, Agee J, McGowan C, Oremland RS, Thomas M, Krabbenhoft DP, Gilmour CC (2000) Methyl-Mercury Degradation Pathways: A Comparison among Three Mercury-Impacted Ecosystems. Environ Sci Technol 34 :4908-4916

Marvin-DiPasquale MC, Lutz MA, Brigham ME, Krabbenhoft DP, Aiken GR, Orem WR, Hall BD (2009) Mercury cycling in stream ecosystems- 2. Benthic methylmercury production and bed sediment pore water partitioning. Environ Sci Technol 43:2726-2732

Mathews TJ, Southworth G, Peterson MJ, Roy WK, Ketelle RH, Valentine C, Gregory S (2013) Decreasing Aqueous Mercury Concentrations to Meet the Water Quality Criterion in Fish: Examining the Water-Fish Relationship in Two Point-Source Contaminated Streams. Sci Total Environ 443:836-848

Mason RP (2012) The Methylation of Metals and Metalloids in Aquatic Systems. Chap. 11. In: Methylation - From DNA, RNA and Histones to Diseases and Treatment. Dricu A editor. pp 271-301. INTECH Open Science. ISBN 978-953-51-0881-8

Mason RP, Lawrence AL (1999) Concentration, distribution, and bioavailability of mercury and methylmercury in sediments of the Baltimore harbour and Chesapeake bay, Maryland, USA. Environ Toxicol Chem 18:2438-2447

Mason RP, Lawson NM, Lawrence AL, Leaner JJ, Lee JG, Sheu GR (1999) Mercury in Chesapeake Bay. Mar Chem 65:77-86

Mikac N, Niessen S, Ouddane B, Wartel M (1999) Speciation of mercury in sediments of the Seine estuary (France). Appl Org Chem 13:715-725

Mikac N, Foucher D, Clarisse O, Niessen S, Lojen S, Logar M, Horvat M, Leermarkers M (2004) Relationship between mercury species and solid sulfides in aquatic sediments. RMZ - Materials and Geoenvironment 51 (Part 2): 1214-1217

Muhaya B, Leermakers M, Baeyens W (1997) Total mercury and methylmercury in sediments and in the polychaete Nereis diversicolor at Groot Buitenschoor (Scheldt estuary, Belgium). Wat Air Soil Pollut 94:109-123

Muresan B, Cossa D, Jézéquel D, Prévot F, Kerbellec S (2007) The biogeochemistry of mercury at the sediment water interface in the Thau lagoon. 1. Partition and speciation. Est Cstl Shelf Sci 72:472-484

Oremland RS, Culbertson CW, Winfrey MR (1991) Methylmercury decomposition in sediments and bacterial cultures: involvement of methanogens and sulfate reducers in oxidative demethylation. Appl Environ Microb 57:130-137

Pak KR, Bartha R (1998) Mercury Methylation by Interspecies Hydrogen and Acetate Transfer between Sulfidogens and Methanogens. Appl Environ Microb, 64:1987-1990

Parks JM, Johs A, Podar M, Bridou R, Hurt RA, Smith SD, Tomanicek SJ, Qian Y, Brown SD, Brandt CC, Palumbo AV, Smith JC, Wall JD, Elias DA, Liang L (2013) The Genetic Basis for Bacterial Mercury Methylation. Science, doi: 10.1126/science.1230667 
Pearson AJ, Bruce KD, Osborn AM, Ritchie DA, Strike P (1996) Distribution of class II transposase and resolvase genes in soil bacteria and their association with mer genes. Appl Environ Microb 62:2961-2965

Ranchou-Peyruse M, Monperrus MR, Bridou R, Duran R, Amouroux D, Salvado JC, Guyoneaud R (2009) Overview of mercury methylation capacities among anaerobic bacteria including representatives of the sulfate-reducers: implications for environmental studies. GeoMicrob J 26:1-8

Ravichandran M (2004) Interactions between mercury and dissolved organic matter - a review. Chemosphere 55:319-331

Rigaud S, Radakovitch O, Couture R-M, Deflandre B, Cossa D, Garnier C, Garnier J-M (2013) Mobility and fluxes of trace elements and nutrients at the sediment-water interface of a lagoon under contrasting water-column oxygenation. Appl Geochem $31: 35-51$

Segade SR, Dias T, Ramalhosa E (2010) Mercury methylation versus demethylation: Main processes involved. Chap 7. In: Methylmercury: Formation, Sources and Health Effects. Clampet AP editor. 32p. Nova Science Publishers, Inc. ISBN: 978-1-61761-838-3

Schaefer JK, Letowski J, Barkay T (2002) mer -Mediated Resistance and Volatilization of Hg(II) Under Anaerobic Conditions. Geomicrobiol J 19:87-102

Schaefer JK, Yagi J, Reinfelder JR, Cardona T, Ellickson KM, Tel-Or S, Barkay T (2004) Role of the bacterial organomercury lyase (MerB) in controlling methylmercury accumulation in mercury-contaminated natural waters. Environ Sci Technol 38:43044311

Schaefer JK, Morel FM (2009) High methylation rates of mercury bound to cysteine by Geobacter sulfurreducens. Nature Geoscience 2:123-126

Schartup AT, Mason RP, Balcom PH, Hollweg TA, Chen CY (2013). Methylmercury Production in Estuarine Sediments: Role of Organic Matter. Environ Sci Technol $47: 695-700$

Sparling R (2009) Biogeochemistry: Mercury methylation made easy. Nature Geoscience 2, 92-93

Sunderland EM, Gobas FAPC, Branfireun BA, Heyes A (2006) Environmental controls on the speciation and distribution of mercury in coastal sediments. Mar Chem 102:11-123

Tessier E, Garnier C, Mullot J-U, Lenoble V, Arnaud M, Raynaud M, Mounier S (2011) Study of the spatial and historical distribution of sediment inorganic contamination in the Toulon bay (France). Mar Pollut Bull 62:2075-2086

Ullrich SM, Tanton TW Abdrashitova SA (2001) Mercury in the aquatic environment: a review of factors affecting methylation. Crit Rev Environ Sci Technol 31:241-293

Vonk JW, Sijpesteijn AK (1973) Studies on the methylation of mercuric chloride by pure cultures of bacteria and fungi. Antonie van Leeuwenhoek 39:505-513

Yu RQ, Adatto I, Montesdeoca MR, Driscoll CT, Hines ME, Barkay T (2010) Mercury methylation in sphagnum moss mats and its association with sulfate-reducing bacteria in an acidic Adirondack forest lake wetland. FEMS Microbiology Ecology 74:655-668

Yu RQ, Flanders JR, Mack EE, Turner R, Mirza B, Barkay T (2012) Contribution of coexisting sulfate and iron reducing bacteria to methylmercury production in freshwater river sediments. Environ Sci Technol 46:2684-2691 
Table 1. Sources of published data used in the Michaelis-Menten model. ${ }^{1}$ Data compilation.

\begin{tabular}{ll}
\hline Area & Reference \\
\hline $\begin{array}{l}\text { Lebanese coast } \\
\text { Patuxent estuary }\end{array}$ & Abi-Ghanem et al. (2011) \\
$\begin{array}{l}\text { Rivers, lakes, wetlands and marine margins } \\
\text { Karlshäll, Köpmanholmen and } \quad \text { Skutskär }\end{array}$ & $\begin{array}{l}\text { Benoit et al. (1998) } \\
\text { estuaries }\end{array}$ \\
$\begin{array}{l}\text { Venice lagoon } \\
\text { Long lsland sound }\end{array}$ & Han et al. (2008) \\
New England shelf & Hammerschmidt and Fitzgerald (2004) \\
Elbe river & Hammerschmidt and Fitzgerald (2006) \\
& Hintelmann and Wilken (1995) \\
$\begin{array}{l}\text { Western Atlantic shelf and slope } \\
\text { Kastela bay, Krka and Öre estuaries }\end{array}$ & Hollweg et al. (2010) \\
Chesapeake bay & Kwokal et al. (2002), Mikac et al. (2004) \\
& Mason and Lawrence (1999), Mason et al. \\
Seine estuary & (1999) \\
Rupel, Deule, Seine and Soča rivers & Mikac et al. (1999) \\
Scheldt estuary & Mikac et al. (2004) \\
Thau lagoon & Muhaya et al. (1997) \\
Berre lagoon & Muresan et al. (2007) \\
Passamaquoddy bay & Rigaud et al. (2013) \\
\hline
\end{tabular}


Table 2. $K_{m}$ values for Michaelis-Menten type relationships between $\mathrm{MeHg}\left(\mathrm{nmol} \mathrm{g}^{-1}\right)$ and $\mathrm{HgT}\left(\mathrm{nmol} \mathrm{g}^{-1}\right.$ ) within various sediment types (values obtained keeping the asymptotic $a$ parameter of the equation fixed at $0.277 \mathrm{nmol} \mathrm{g}^{-1}$ ). (1) data defining the asymptotic value of the equation, i.e. from Sweden riverine and estuarine sediments, heavily contaminated by chlor-alkali activities (Drott et al. 2008).

\begin{tabular}{|c|c|c|c|c|}
\hline Type of sediment & $K_{m}$ & $\begin{array}{c}\mathrm{R}^{2}(\mathrm{n}) \\
\mathrm{p}\end{array}$ & Location & $\begin{array}{l}\text { HgT level } \\
\left(\mathrm{nmol} \mathrm{g}^{-1}\right)\end{array}$ \\
\hline $\begin{array}{l}\text { Highest points } \\
(5 \%)\end{array}$ & $14 \pm 2$ & $\begin{array}{l}0.94(72) \\
<0.0001\end{array}$ & $\begin{array}{l}\text { Surface sediment from various } \\
\text { region (and heavily } \\
\text { contaminated sediments) }\end{array}$ & $\begin{array}{c}<1 \\
(\text { and }>100)^{1}\end{array}$ \\
\hline Lowest points $(5 \%)$ & $\begin{array}{c}1870 \pm \\
70\end{array}$ & $\begin{array}{l}0.93(72) \\
<0.0001\end{array}$ & $\begin{array}{c}\text { Toulon and Kastela bays, Venice } \\
\text { and Berre lagoons, Elbe, Seine and } \\
\text { Soča rivers and estuaries }\end{array}$ & $10-1000$ \\
\hline Surface $(<2 \mathrm{~cm})$ & $139 \pm 12$ & $\begin{array}{l}0.41(226) \\
<0.0001\end{array}$ & All sites & $<1-1000$ \\
\hline $\operatorname{Deep}(>10 \mathrm{~cm})$ & $223 \pm 10$ & $\begin{array}{l}0.75(550) \\
<0.0001\end{array}$ & All sites & $<1-1000$ \\
\hline Rivers & $327 \pm 38$ & $0.38(149)$ & Deule, Elbe, Rupel, Seine, Soča & $>1$ \\
\hline Estuaries & $159 \pm 20$ & $\begin{array}{l}0.64(171) \\
<0.0001\end{array}$ & $\begin{array}{c}\text { Krka, Karlshäll, Köpmanholmen, } \\
\text { Öre, Patuxent, Seine, Scheldt and } \\
\text { Skutskär estuaries }\end{array}$ & $>0.1$ \\
\hline Lagoons & $223 \pm 16$ & $\begin{array}{c}0.10(201) \\
\quad<0.10\end{array}$ & $\begin{array}{l}\text { Berre, Pierre-Blanche, Thau and } \\
\text { Venice (Mediterranean lagoons) }\end{array}$ & $0.1-10$ \\
\hline Bays and shelves & $168 \pm 5$ & $\begin{array}{l}0.79(642) \\
<0.0001\end{array}$ & $\begin{array}{l}\text { Chesapeake, Kastela, } \\
\text { Passamaquoddy and Toulon bays, } \\
\text { Lebanese coast, Rhone delta, Long } \\
\text { Island Sound }\end{array}$ & $<1-1000$ \\
\hline Open sea & $89 \pm 8$ & $\begin{array}{l}0.31(277) \\
<0.0001\end{array}$ & $\begin{array}{c}\text { Abyssal plains and slope (Arctic } \\
\text { Ocean, Mediterranean Sea } \\
\text { Atlantic Ocean) }\end{array}$ & $<1$ \\
\hline Abyssal plain & $\begin{array}{c}24.7 \pm \\
0.2\end{array}$ & $\begin{array}{l}0.99(260) \\
<0.0001\end{array}$ & $\begin{array}{c}\text { Mediterranean Sea and Arctic } \\
\text { Ocean }\end{array}$ & $<0.5$ \\
\hline
\end{tabular}




\section{Figures}

Figure 1. Overall Michaelis-Menten type relationship $(p<0.001)$ between 1442 couples of $\mathrm{MeHg}$ and $\mathrm{HgT}$ concentrations in aquatic sediments. MeHg/HgT couples from various aquatic sediments including marine abyssal, coastal, lagoonal, estuarine, lacustrine and riverine sediments ranging from pristine environments to heavily polluted ones, and from aerobic to sulfidic environments. The gathered data used here originate from published (Table 1) and present authors' unpublished works. When figure data were not available the DigiSoft program (available free for download at http://gss.srce.hr/pithos/rest/omanovic@irb.hr/files/Software/) software was used to convert data points of the published graphs into numerals.

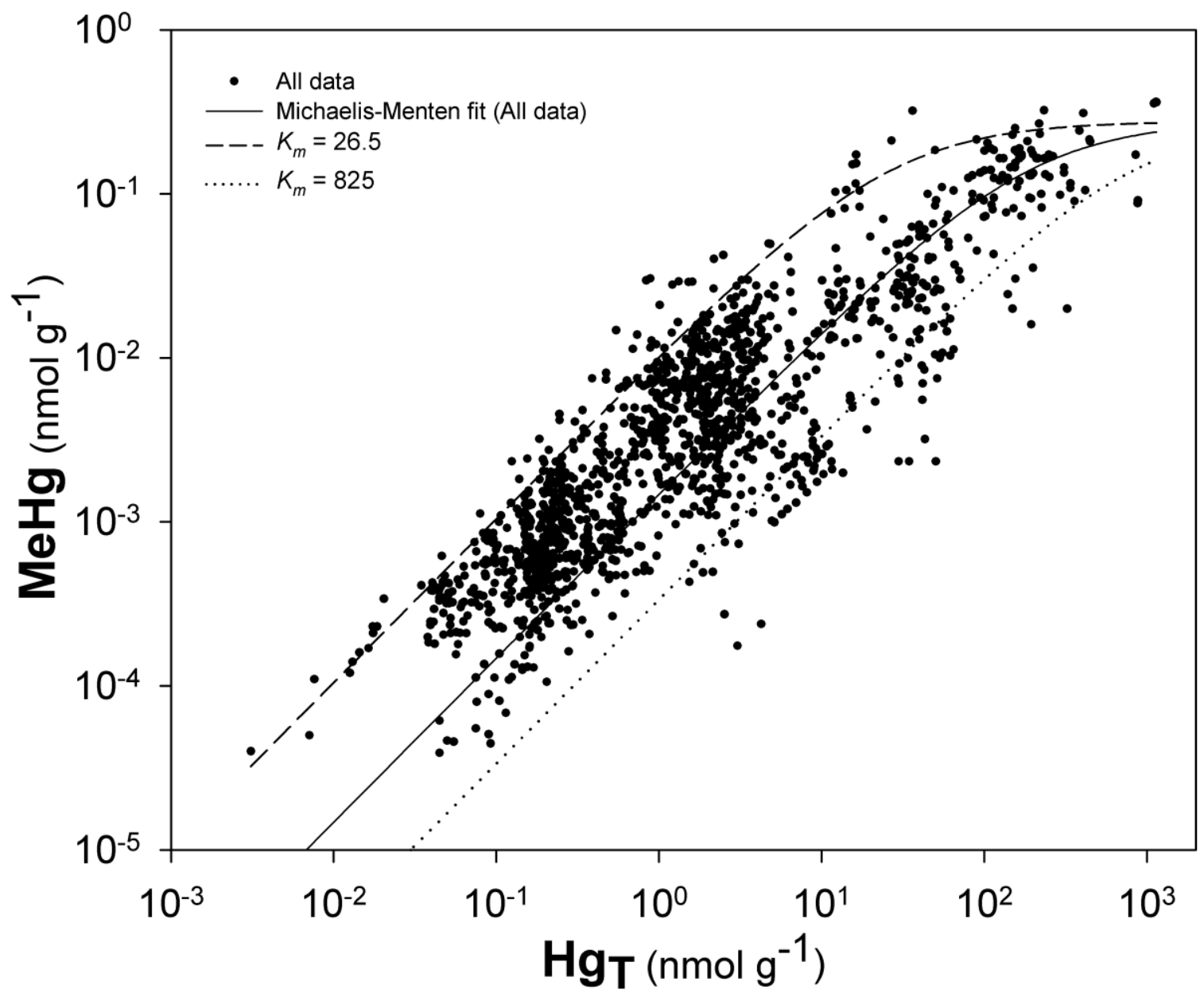


Figure 2. Relationship $(\mathrm{p}<0.001)$ between $\mathrm{MeHg} / \mathrm{HgT}$ ratios and amino acid (proxy of labile organic matter) in the sediment of the Cap de Creus canyon (NW Mediterranean).

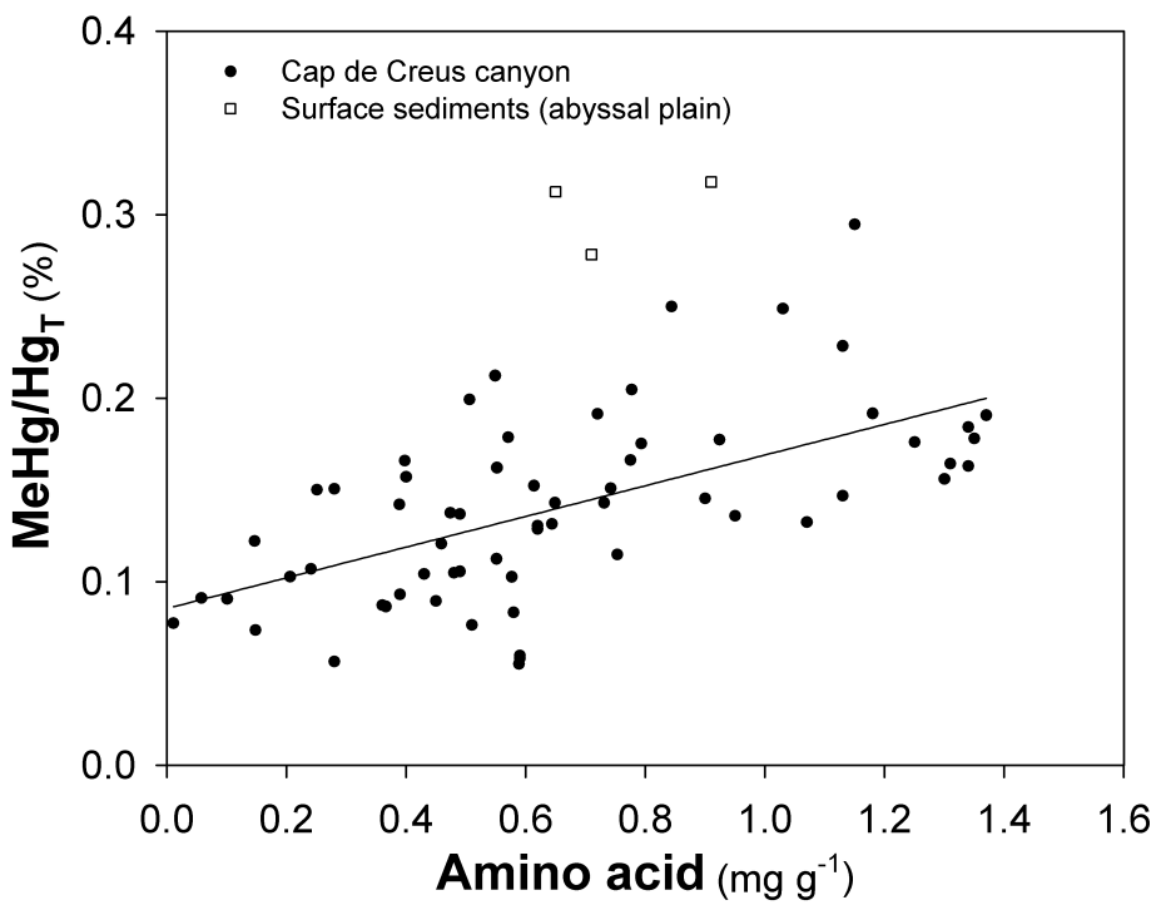


Figure SI 1. The Michealis-Menten model with upper and lower ratio lines in gray (see text for more explanation)

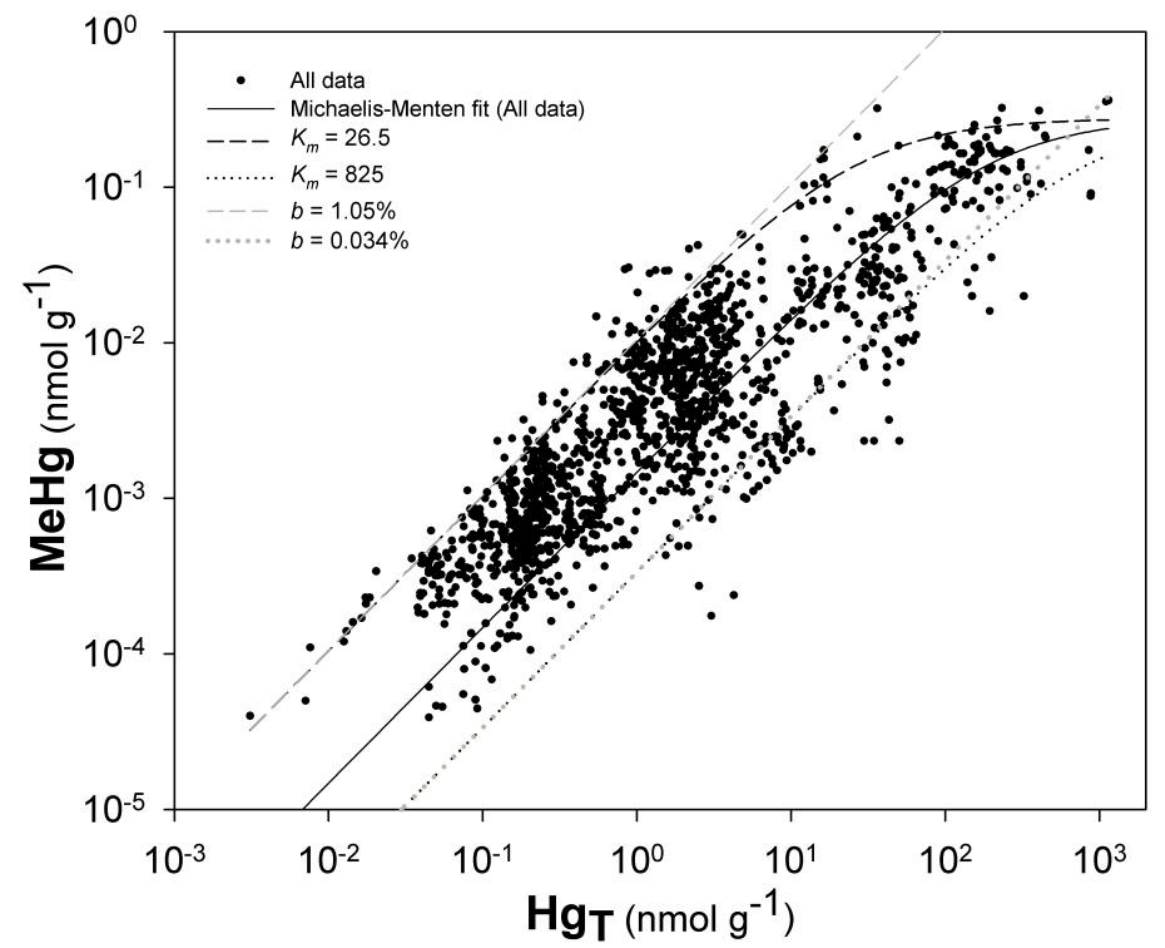


Figure SI 2. Variation of $\mathrm{MeHg} / \mathrm{HgT}$ ratio vs $\mathrm{HgT}$ concentration $(\mathrm{N}=1442)$

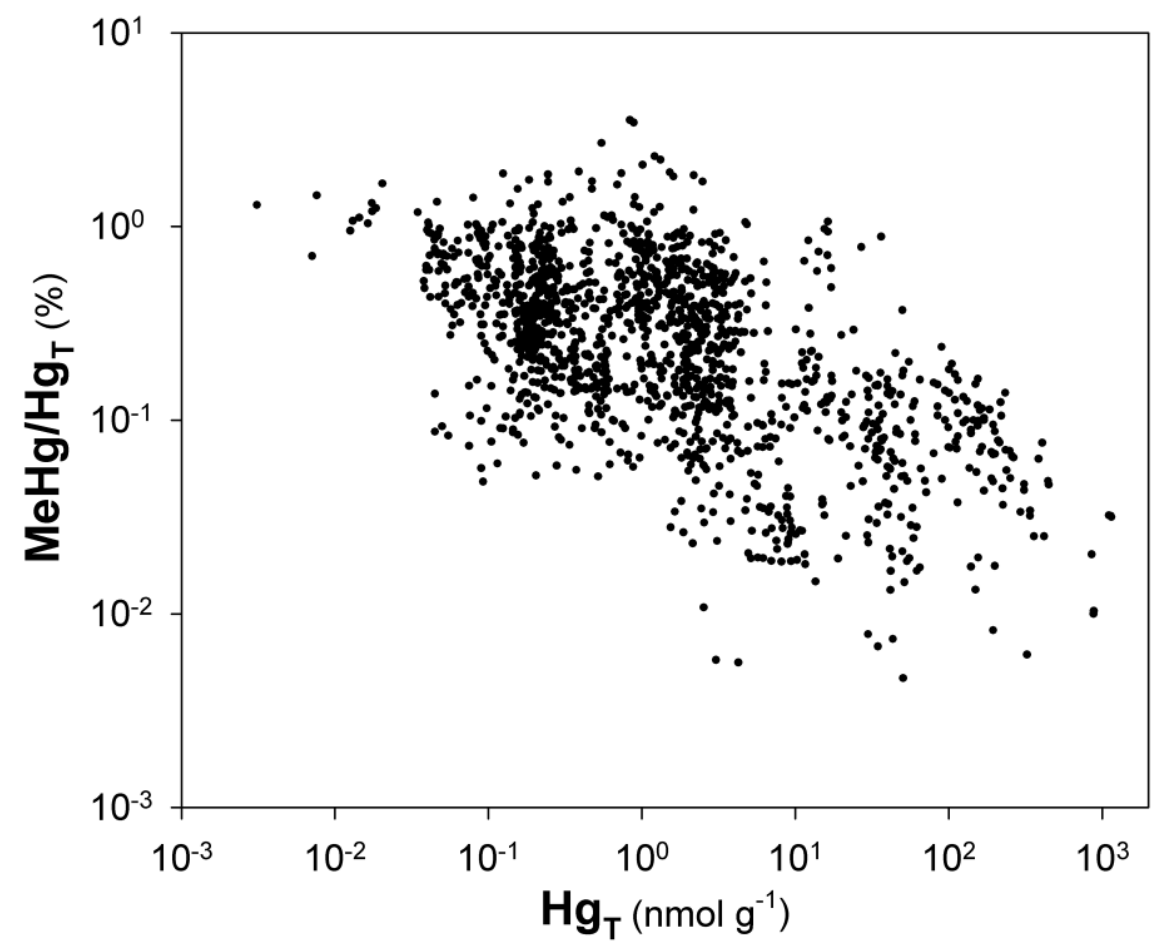


Figure SI 3. Variation of (A) $\mathrm{HgT}$, (B) $\mathrm{MeHg}$ and (C) $\mathrm{MeHg} / \mathrm{HgT}$ ratio vs organic carbon content $(\mathrm{N}=617)$
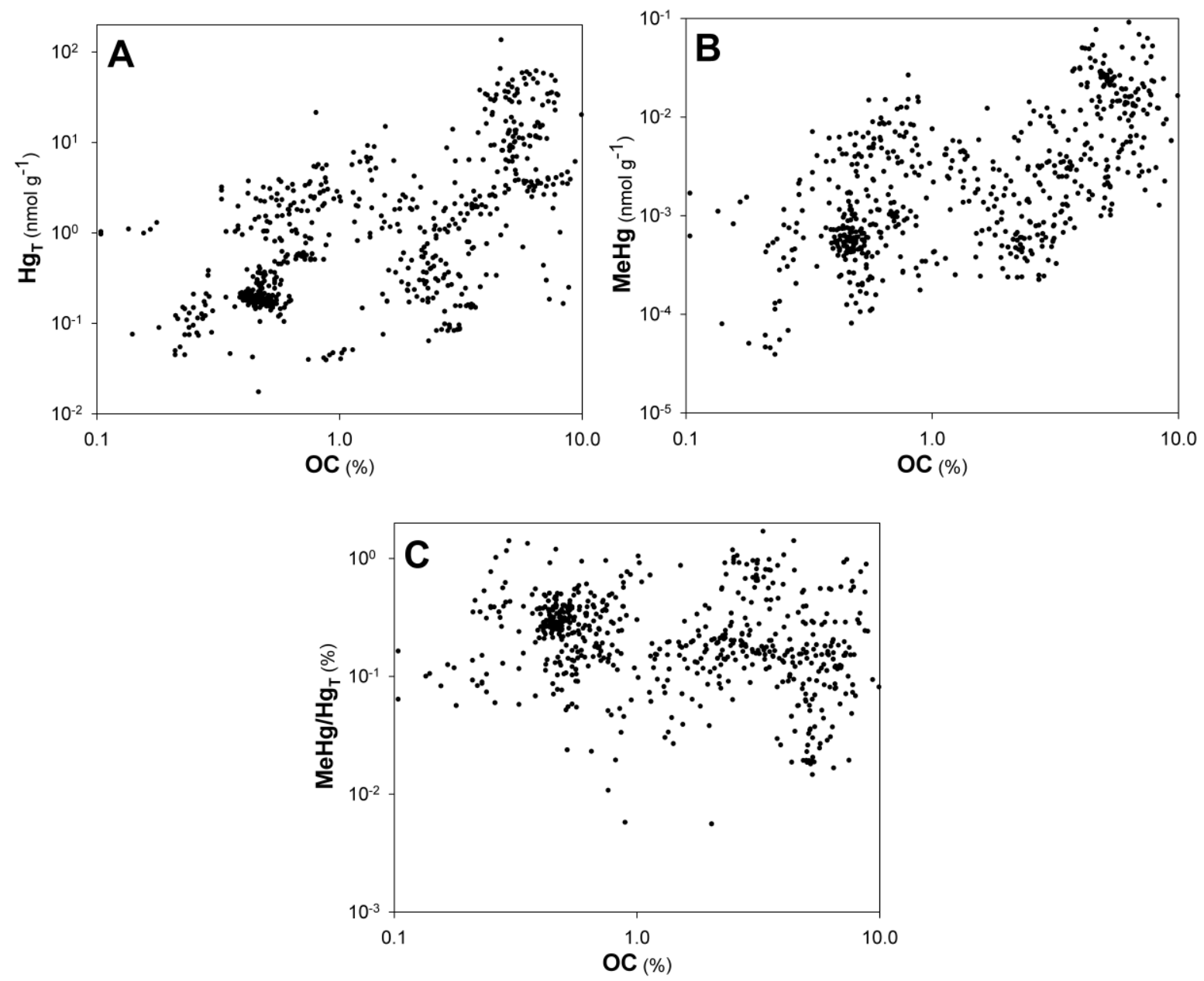